\title{
KEMAMPUAN PEMAHAMAN MATEMATIK SISWA MTS DI CIMAHI PADA MATERI PERSAMAAN GARIS LURUS
}

\author{
Suswigi ${ }^{1}$, Luvy S. Zanthy ${ }^{2}$ \\ ${ }^{1,2}$ Pendidikan Matematika, IKIP SILIWANGI \\ Jl. Terusan Jendral Sudirman Cimahi 40526 \\ wigimath1@gmail.com
}

One of the mathematical abilities that students must possess is mathematical comprehension skills. This study aims to analyze students' mathematical understanding skills in the material of straight-line equations. This type of research is qualitative research with class VIII students in one of the MTs Cimahi as the research subject. The data collection technique was carried out by giving a test in the form of a mathematical comprehension ability as many as 5 items with the analysis technique used was the percentage of each item, interview and conclusion. Based on the results of tests of mathematical comprehension abilities that have been analyzed, the average percentage score of the students' mathematical comprehension ability of $53.87 \%$ is classified as low. It can be concluded that the ability of mathematical understanding of MTs students in Cimahi City on straight line equation material is still low.

Keywords: Mathematical Understanding

\section{Abstrak}

Salah satu kemampuan matematik yang harus dimiliki siswa adalah kemampuan pemahaman matematik. Penelitian ini bertujuan untuk menganalisis kemampuan pemahaman matematik siswa pada materi persamaan garis lurus. Jenis penelitian ini adalah penelitian kualitatif dengan siswa kelas VIII di salah satu MTs Cimahi sebagai subjek penelitian. Teknik pengambilan data dilakukan dengan pemberian tes berupa soal kemampuan pemahaman matematik sebanyak 5 butir soal dengan teknik analisis yang digunakan adalah persentase tiap butir soal, wawancara dan penarikan kesimpulan. Berdasarkan hasil tes kemampuan pemahaman matematik yang telah dianalisis, diperoleh rata-rata persentase skor kemampuan pemahaman matematik siswa sebesar 53,87\% yang tergolong rendah. Dapat disimpulkan bahwa kemampuan pemahaman matematik siswa MTs di Kota Cimahi pada materi persamaan garis lurus tergolong masih rendah.

Kata Kunci: Pemahaman Matematik

Kurikulum 2013 (K-13) adalah kurikulum baru yang berlaku pada sistem pendidikan Indonesia saat ini. Kurikulum ini merupakan kurikulum yang diterapkan oleh pemerintah untuk menggantikan kurikulum 2006 (KTSP) yang akrab dengan sebutan kurtilas. Kurikulum 2013 masuk dalam masa percobaan pada tahun 2013 dengan menjadikan beberapa sekolah menjadi sekolah rintisan. Berdasarkan peraturan pemerintah pendidikan dan kebudayaan No. 60 tahun 2014, Desember, pelaksanaan kurikulum 2013 dihentikan dan sekolah-sekolah kembali menggunakan kurikulum KTSP untuk sementara, kecuali bagi sekolah dasar dan menengah yang sudah melaksanakan kurtilas selama 3 semester. 
Pembelajaran matematika, dengan materi yang cukup padat menjadi beban yang cukup berat bagi siswa untuk berprestasi secara maksimal. Minat belajar siswa dalam mengikuti pelajaran matematika kurang, hasil yang diperoleh belum sesuai dengan yang diharapkan. Pelajaran matematika memiliki peranan penting dalam kehidupan sehari-hari karena matematika dapat membentuk pola pikir dengan matematika termasuk ke dalam ilmu eksakta yang lebih banyak memerlukan pemahaman dibandingkan dengan hapalan. Hal ini sejalan dengan pendapat Puspitasari, Purwasih, Nurjaman \& Wahyuni (2017) bahwa "aktifitas pembelajaran matematika merupakan suatu proses untuk pembentukan mindsite agar tercipta pola pikir yang sistematis dari yang mudah sampai yang sukar”. Menurut Hendriana dan Soemarmo (2014) mengatakan bahwa "berdasarkan jenisnya, kemampuan matematik dapat diklasifikasikan dalam lima kompetensi utama yaitu: pemahaman matematik, pemecahan masalah, komunikasi matematik, koneksi matematik dan penalaran matematik".

Berdasarkan hal tersebut, bahwa kemampuan pemahaman matematik sangat penting dimiliki oleh siswa dalam memperlajari pelajaran matematika karena kemampuan pemahaman matematik adalah tahap awal untuk bisa menyelesaikan suatu permasalah matematika yang ditemukan. Sejalan dengan yang dikemukakan Sariningsih (2014) bahwa kemampuan pemahaman matematis penting untuk dimiliki siswa karena kemampuan tersebut merupakan prasyarat seseorang untuk memiliki kemampuan pemecahan masalah matematis. Namun kenyataan di lapangan menunjukkan bahwa kemampuan pemahaman matematik siswa masih relatif rendah dimana siswa hanya menghapal rumus tanpa mengetahui dari mana rumus tersebut diperoleh, hal ini sejalan dengan penelitian yang dilakukan oleh Sari, Rismayanti \& Pusptasari (2018) menyimpulkan bahwa "kemampuan pemahaman dan pemecahan masalah matematik siswa MTs di Kabupaten Cianjur masih tergolong rendah”. Putra, Setiawan, Nurdianti, Retta \& Desi (2018) menunjukan “... presentase kemampuan pemahaman matematik siswa SMP yaitu sebesar $41,67 \%$ siswa berkemampuan rendah, 30,56\% siswa berkemampuan sedang dan 27,72\% siswa berkemampuan tinggi”. Apriasyah \& Ramdani (2018) menyimpulkan bahwa "kemampuan pemahaman dan berpikir kreatif matematik siswa SMP pada materi Bangun Ruang Sisi Datar termasuk dalam kategori rendah".

Menurut NCTM (Apriansyah \& Ramdani, 2018) Kemampuan pemahaman matematik memiliki indikator-indikator sebagai berikut, 1) mendefinisikan konsep secara verbal dan tulisan, 2) mengidentifikasi dan membuat contoh dan bukan contoh, 3) menggunakan model, diagram dan simbol-simbol untuk mempresentasikan suatu konsep, 4) mengubah suatu bentuk representasi ke bentuk lain, 5) mengenal berbagai makna dan interpretasi konsep, 6) mengidentifikasi sifat-sifat suatu konsep dan mengenal syarat yang menentukan suatu konsep dan 7) membandingkan dan membedakan konsep-konsep.

Penelitian ini menggunakan empat indikator kemampuan pemahaman matematika, yaitu: 1) mendefinisikan konsep secara verbal dan tulisan, 2) mengidentifikasi dan membuat contoh dan bukan contoh, 3) menggunakan model, diagram dan simbol-simbol untuk mempresentasikan suatu konsep dan 4) mengidentifikasi sifat-sifat suatu konsep dan mengenal syarat yang menentukan suatu konsep. 
Indikator tersebut dapat menjadi tolak ukur untuk mengukur kemampuan pemahaman matematik siswa. Berdasarkan latar belakang tersebut, penelitian ini bertujuan untuk mengetahui sejauh mana kemampuan pemahaman matematik yang dimiliki siswa MTs pada materi persamaan garis lurus.

\section{METODE}

Penelitian ini bertujuan untuk menganalisis kemampuan pemahaman matematik siswa MTs pada materi persamaan garis lurus. Jenis penelitian ini adalah penelitian kualitatif dengan siswa kelas VIII A di salah satu MTs di Cimahi sebagai subjek penelitian yang terdiri dari 34 siswa, namun pada saat pemberian tes hanya 31 siswa yang hadir. Teknik pengambilan data dilakukan dengan pemberian tes berupa soal kemampuan pemahaman matematik sebanyak 5 butir soal. Menurut Nawawi (Akbar, Hamid, Bernard \& Sugandi, 2018) "tes essai adalah tes yang mengkehendaki testee (perertas tes) memberikan jawaban dalam bentuk uraian atau kalimat-kalimat yang disusun sendiri" dan tes menurut Hartono (Revita, Kurniati \& Andriani, 2018) "serangkaian pertanyaan atau latihan yang digunakan untuk mengukur pengetahuan, kemampuan atau bakat atau intelegensia, keterampilan yang dimiliki oleh individu atau kelompok“. Sebelum tes tersebut diteskan kepada subjek, soal sudah dalam keadaan valid secara teoritis dengan pertimbangan dosen-dosen ahli dan secara empiris dengan soal tersebut diujikan terlebih dahulu kepada siswa diluar subjek penelitian yaitu kelas IX. Teknik analisis data dalam penelitian ini mengunakan persentase tiap butir soal, wawancara dan penarikan kesimpulan. Dalam persentase tiap butir soal menggunakan klasifikasi tingkat persentase kemampuan pemahaman matematik seperti pada Tabel 1 berikut ini.

Tabel 1.

Klasifikasi Presentase Skor Kemampuan Pemahaman Matematik

\begin{tabular}{|c|c|}
\hline Persentase Kemampuan & Interpretasi \\
\hline $0-34 \%$ & Sangat Rendah \\
\hline $35 \%-54 \%$ & Rendah \\
\hline $55 \%-64 \%$ & Sedang \\
\hline $65 \%-84 \%$ & Tinggi \\
\hline $85 \%-100 \%$ & Sangat Tinggi \\
\hline
\end{tabular}

\section{HASIL DAN PEMBAHASAN}

Berdasarkan penelitian yang dilakukan di kelas VIII A di salah satu MTs di Kota Cimahi diperoleh hasil data siswa dari tes kemampuan pemahaman matematik seperti pada Tabel 2 berikut.

\section{Tabel 2.}

Presentase Skor Kemampuan Pemahaman Matematik

\begin{tabular}{|c|c|l|}
\hline No Soal & $\boldsymbol{\%}$ & \multicolumn{1}{|c|}{ Interpretasi } \\
\hline 1 & 100.00 & Sangat Tinggi \\
\hline 2 & 48.39 & Rendah \\
\hline 3 & 25.00 & Sangat Rendah \\
\hline
\end{tabular}




\begin{tabular}{|c|c|l|}
\hline 4 & 70.97 & Tinggi \\
\hline 5 & 25.00 & Sangat rendah \\
\hline Rerata & 53.87 & Rendah \\
\hline
\end{tabular}

Berdasarkan pada Tabel 2 dapat dilihat bahwa presentase pada setiap soal kemampuan pemahaman matematik berbeda. Pada nomor soal 1 memperoleh presentase sebesar $100 \%$ yang artinya kemampuan pemahaman matematik siswa kelas VIII A sangat tinggi dimana setiap siswa menjawab dengan benar. Terlihat pula pada jawaban siswa seperti pada Gambar 1 di bawah ini.

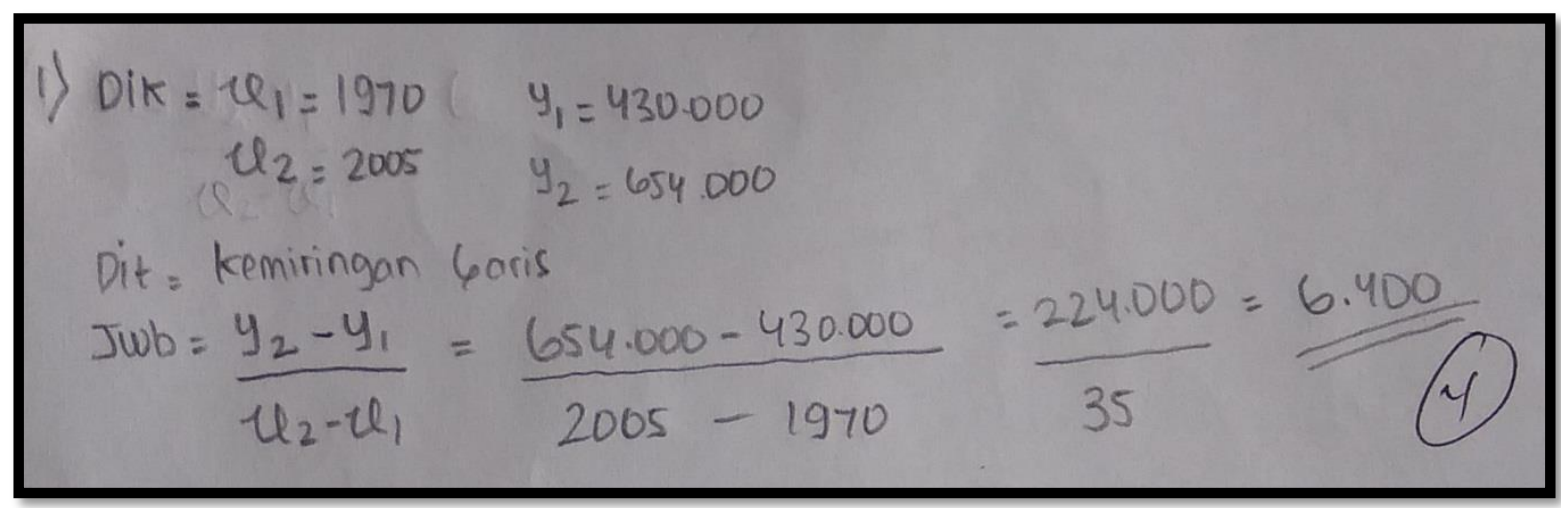

Gambar 1. Jawaban Siswa Soal Nomor 1

Berdasarkan dari jawaban siswa pada Gambar 1, terlihat bahwa siswa mampu menjawab dengan benar yang artinya siswa memahami soal yang diberikan dan memahami konsep yang diberikan. Setelah diselidiki melalui wawancara siswa bahwa siswa memahami soal yang diberikan dan memahami konsep dan prosuderal untuk menyelesaikan soal tersebut dan soal tersebut tergolong mudah.

Pada nomor soal 2 memperoleh presentase sebesar 48,39\% yang artinya kemampuan pemahaman matematik siswa kelas VIII A rendah dimana setiap siswa menjawab dengan benar namun tidak menggunakan konsep persamaan garis lurus dalam menyelesaikan soal tersebut. Terlihat pula pada jawaban siswa seperti pada Gambar 2 di bawah ini.

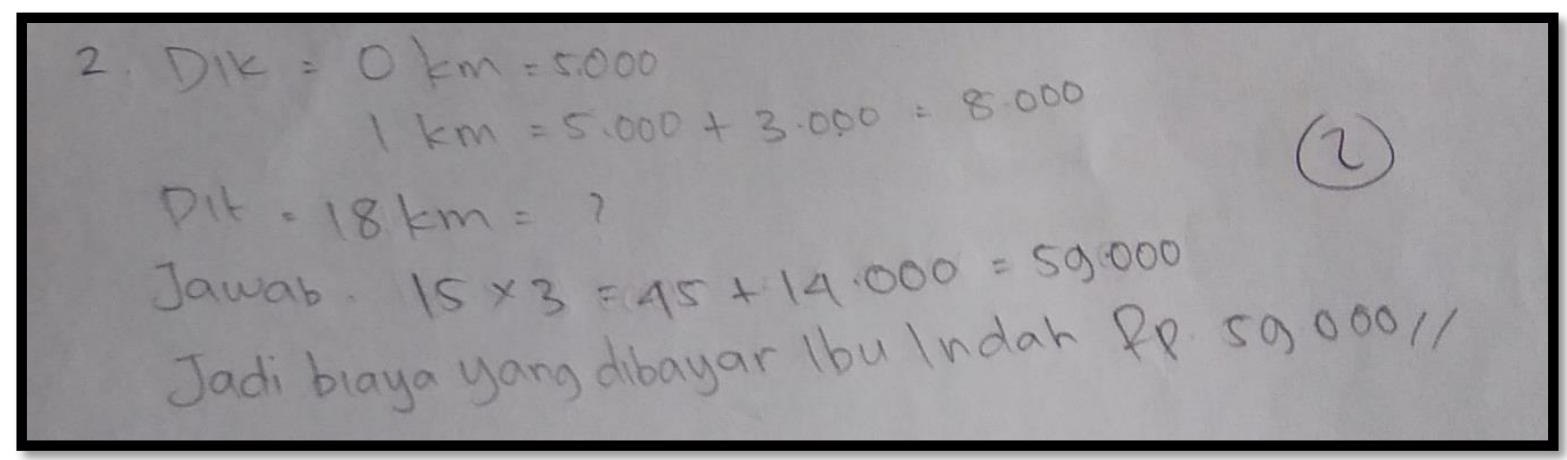

Gambar 2. Jawaban Siswa Soal Nomor 2 
Berdasarkan dari jawaban siswa pada Gambar 2, terlihat bahwa siswa mampu menjawab dengan benar namun tidak sesuai dengan yang diharapkan. Jawaban yang diharapkan adalah penyelesaian soal tersebut menggunakan konsep persamaan garis lurus, sedangkan siswa menjawab soal tersebut dengan konsep lain. Sehingga pada soal nomor 2, kemampuan pemahaman matematik siswa dikategorikan rendah. Setelah diselidiki melalui wawancara siswa bahwa siswa memahami soal yang diberikan dan menyelesaikan soal tersebut dengan konsep pola bilangan dan soal tersebut tergolong mudah.

Pada nomor soal 3 memperoleh presentase sebesar $25 \%$ yang artinya kemampuan pemahaman matematik siswa kelas VIII A sangat rendah dimana setiap siswa tidak dapat menjawab. Terlihat pula pada jawaban siswa seperti pada Gambar 3 di bawah ini.

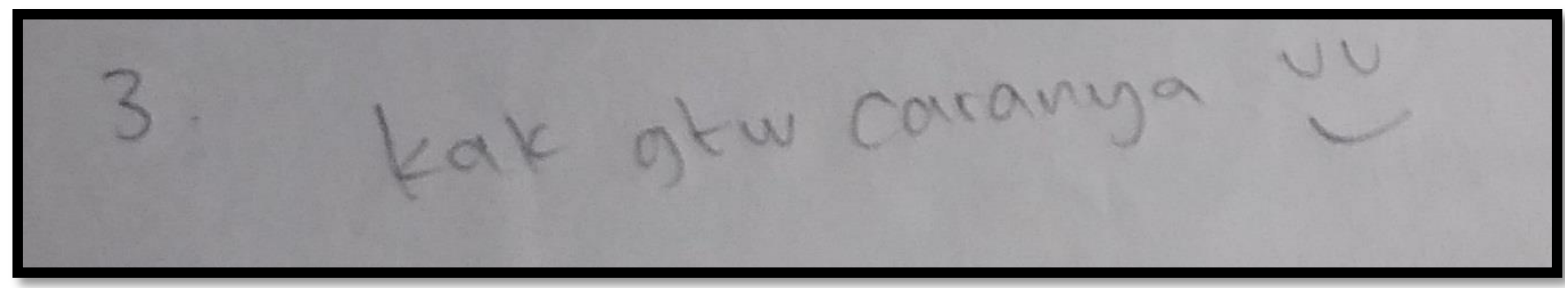

Gambar 3. Jawaban Siswa Soal Nomor 3

Berdasarkan dari jawaban siswa pada Gambar 3, terlihat bahwa siswa tidak mampu menjawab. Sehingga pada soal nomor 3, kemampuan pemahaman matematik siswa dikategorikan sangat rendah. Setelah diselidiki melalui wawancara siswa bahwa siswa memahami soal yang diberikan namun tidak bisa menyelesaikan soal tersebut karena soal yang diberikan belum pernah dipelajari dan termasuk bukan soal rutin sehingga soal tersebut tergolong sulit.

Pada nomor soal 4 memperoleh presentase sebesar $70.97 \%$ yang artinya kemampuan pemahaman matematik siswa kelas VIII A tinggi dimana setiap siswa dapat menjawab dengan benar namun sebagian kecil siswa menyelesaikannya tidak tuntas. Terlihat pula pada jawaban siswa seperti pada Gambar 4 di bawah ini.

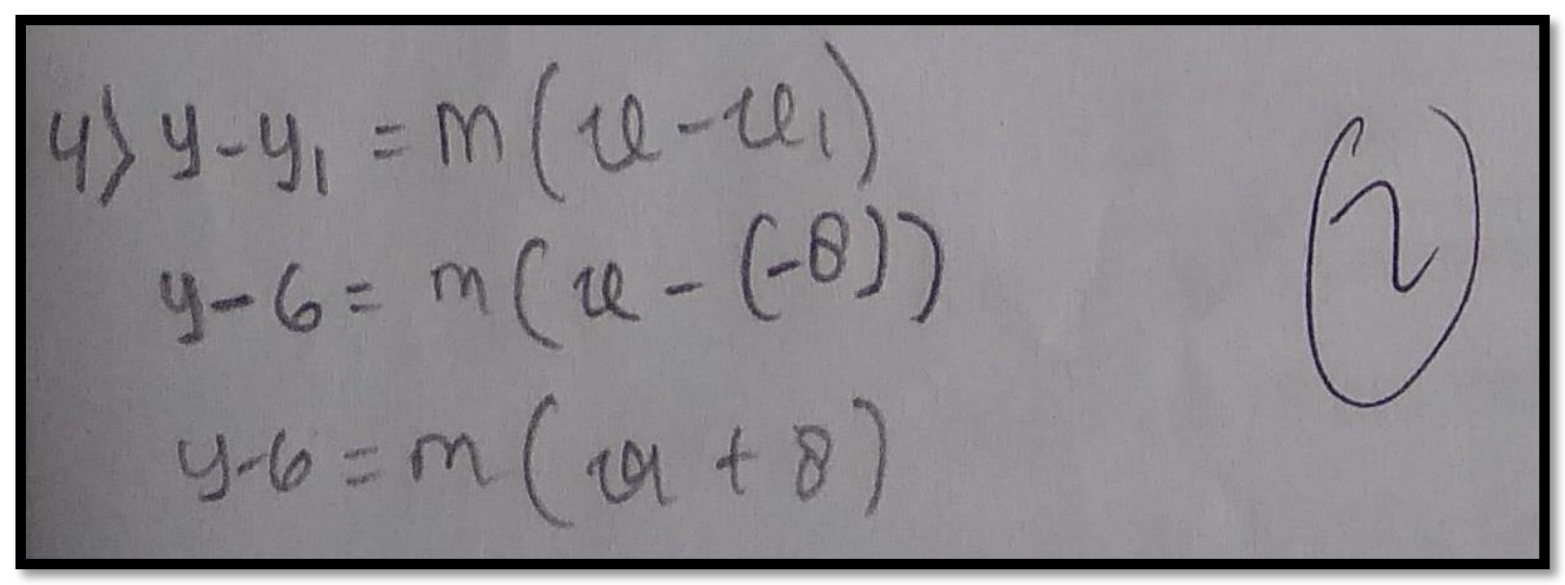

Gambar 4. Jawaban Siswa Soal Nomor 4 
Berdasarkan dari jawaban siswa pada Gambar 4, terlihat bahwa siswa mampu menjawab namun siswa tidak tuntas dalam menyelesaikan soal tersebut dan kurang mengidentifikasi soal sehingga nilai gradiennya tetap variabel $\mathrm{m}$ sedangkan pada soal telah diketahui nilai gradiennya. Dikarenakan hanya sebagian siswa yang mengerjakan soal tersebut tidak tuntas, sehingga pada soal nomor 4, kemampuan pemahaman matematik siswa dikategorikan tinggi dan soal tergolong sedang. Setelah diselidiki melalui wawancara siswa bahwa siswa kurang fokus membaca soal karena waktu yang diberikan untuk mengerjakan soal sudah hampir habis.

Pada nomor soal 5 memperoleh presentase sebesar 25\% yang artinya kemampuan pemahaman matematik siswa kelas VIII A sangat rendah dimana setiap siswa tidak dapat menjawab. Setelah diselidiki melalui wawancara siswa bahwa siswa memahami soal yang diberikan namun tidak bisa menyelesaikan soal tersebut karena siswa belum memahami konsep hubungan garis lurus dan gradien sehingga soal nomor 5 tergolong soal yang sulit.

\section{KESIMPULAN}

Berdasarkan hasil dan pembahasan, terlihat bahwa kemampuan pemahaman matematik siswa pada soal nomor 1 dikategorikan sangat tinggi dengan perolehan presentase sebesar $100 \%$, pada soal nomor 2 dikategorikan rendah dengan presentase sebesar 48,39\%, pada soal nomor 3 dikategorikan sangat rendah dengan presentase sebesar 25\%, pada soal nomor 4 dikategorikan tinggi dengan presentase sebesar 70,97\% dan pada soal nomor 5 dikategorikan rendah dengan presentase sebesar $25 \%$. Rerata dari keseluruhan presentase kemampuan pemahaman matematik yang diperoleh siswa kelas VIII A sebesar 53,87\% sehingga dapat disimpulkan bahwa kemampuan pemahaman matematik siswa kelas VIII di salah satu MTs di Kota Cimahi masih tergolong masih rendah.

Berdasarkan penelitian yang telah dilakukan ada beberapa saran yang diajukan, diantaranya ialah 1) siswa harus diperkuat pemahaman konsep dasar materi persamaan garis lurus, 2) membiasakan siswa untuk lebih teliti dalam membaca soal dan mengerjakannya dan 3) untuk penelitian selanjutnya, untuk mengkaji lebih dalam tentang kemampuan pemahaman matematik siswa karena rendahnya kemampuan pemahaman matematik adalah suatu masalah yang dari dulu belum dituntaskan secara maksimal.

\section{Daftar Pustaka}

Akbar, P., Hamid, A., Bernard, M., \& Sugandi, A. I. (2018). Analisis Kemampuan Pemecahan Masalah dan Disposisi Matematik Siswa Kelas XI SMA Putra Juang dalam Materi Peluang. Jurnal Cendekia: Jurnal Pendidikan Matematika, 2(1), 144-153.

Hendriana, H dan Sumarmo, U. (2014). Penilaian Pembelajaran Matematika. Bandung: PT Refika Aditama. 
Puspitasari, I., Purwasih, R., Nurjaman, A., \& Wahyuni, S. (2017). Analisis Hambatan Belajar Mahasiswa pada Mata Kuliah Program Linear. JIPM (Jurnal Ilmiah Pendidikan matematika), 6(1), 39-46.

Putra, H. D., Setiawan, H., Nurdianti, D., Retta, I., \& Desi, A. (2018). Kemampuan Pemahaman Matematis Siswa SMP di Bandung Barat. Jurnal Penelitian dan Pembelajaran Matematika,11(1).

Ramdani, M., \& Apriansyah, D. (2018). Analisis Kemampuan Pemahaman dan Berfikir Kreatif Matematik Siswa Mts pada Materi Bangun Ruang Sisi Datar. Jurnal Cendekia: Jurnal Pendidikan Matematika, 2(2), 1-7.

Revita, R., Kurniati, A., \& Andriani, L. (2018). Analisis Instrumen Tes Akhir Kemampuan Komunikasi Matematika untuk Siswa SMP pada Materi Fungsi dan Relasi. Jurnal Cendekia: Jurnal Pendidikan Matematika, 2(2), 8-19.

Sari, K. D., Rismayanti, \& Puspitasari, I. (2018). Analisis kemampuan Pemahaman dan Pemecahan Masalah Matematika Siswa MTs pada Materi Bangun Ruang Sisi Datar. JPMI-Jurnal Pembelajaran Matematika Inovatif, 1(5), 965-974.

Sariningsih, R. (2014). Pendekatan Kontekstual untuk Meningkatkan Kemampuan Pemahaman Matematis Siswa SMP. Infinity: Jurnal Ilmiah Program Studi Matematika STKIP Siliwangi Bandung, 3(2), 150-163. 